\title{
Pro-inflammatory activity of Astronium fraxinifolium Schott on Lipopolysaccharide-stimulated RAW 264.7 cells
}

Milena Aguiar Braga ${ }^{1}$, Raphael de Oliveira Rodrigues ${ }^{1 *}$, Juliana Navarro Ueda Yaochite ${ }^{1}$, Greyce Luri Sasahara ${ }^{1}$, Ana Flavia Seraine Custodio Viana ${ }^{2}$, Paulo Iury Gomes Nunes ${ }^{2}$, Karina Moura Melo², Flavia Almeida Santos ${ }^{2}$, Maria Jania Teixeira ${ }^{3}$, Joao Tavares Calixto Junior ${ }^{4}$, Ana Livya Moreira Rodrigues 5 , Selene Maia de Morais ${ }^{5}$, Aparecida Tiemi Nagao-Dias ${ }^{1}$

${ }^{1}$ Department of Clinical Analysis and Toxicology, Faculty of Pharmacy, Universidade Federal do Ceara (UFC), 60430-370 Fortaleza, Brazil. ${ }^{2}$ Department of Physiology and Pharmacology, Faculty of Medicine, Universidade Federal do Ceara (UFC), 60430-270 Fortaleza, Brazil. ${ }^{3}$ Department of Pathology and Legal Medicine, Faculty of Medicine, Universidade Federal do Ceara (UFC), 60430-350 Fortaleza, Brazil. ${ }^{4}$ Department of Biological Sciences, Universidade Regional do Cariri (URCA), 63105-000 Crato, Brazil.

${ }^{5}$ Laboratory of Natural Products, Universidade Estadual do Ceará, Science and Technology Center, Itaperi, 60714903 Fortaleza, Brazil.

\section{ARTICLE INFO \\ Received on: 28/02/2019 \\ Accepted on: 19/10/2019 \\ Available online: 03/12/2019}

\section{Key words:}

Astronium fraxinifolium, inflammatory mediators, RAW 264.7 cells, LPS, inflammation.

\begin{abstract}
This study aimed to investigate the antioxidant and immunomodulating activities of ethanolic extract from the sapwood of Astronium fraxinifolium (EEAF) on Lipopolysaccharide (LPS)-stimulated RAW 264.7 cells. The constituents of the EEAF were analyzed by high-performance liquid chromatography (HPLC). Antioxidant activity of EEAF was evaluated by its capacity of inhibiting the production of free radical 2,2'-diphenyl-1-picrylhydrazyl and 2,2-azino-bis3-ethylbenzothiazoline-6-sulfonic acid. For the analysis of its immunomodulatory properties, Nitric oxide (NO), tumor necrosis factor alpha (TNF- $\alpha$ ), and transforming growth factor beta (TGF- $\beta$ ) levels were determined in supernatants from LPS-stimulated RAW 264.7 cells after treatment with the EEAF at different concentrations. Expression for mRNA of Cyclooxygenase-2 (COX-2) and Inducible nitric oxide synthase (iNOS), and detection of COX-2 protein were also analyzed. Caffeic acid, quercetin, followed by orientin and $\rho$-coumaric acid, were identified in the extract by the HPLC technique. The EEAF showed poor antioxidant activity when compared to the reference standard. NO, expression of COX-2 mRNA and COX-2 protein were found in high levels when LPS-stimulated cells were treated with the EEAF. Moreover, increased levels of TNF- $\alpha$ and low secretion of TGF- $\beta$ were demonstrated in supernatants from LPS-stimulated cells treated with EEAF at different concentrations. In opposition to many different types of medicinal plants, the EEAF demonstrated a powerful pro-inflammatory capacity.
\end{abstract}

\section{INTRODUCTION}

Astronium fraxinifolium Schott, popularly known as Gonçalves-alves, gonçaleiro, and aroeira-do-campo, belongs to the Anacardiaceae family and can be found on rocky and dry lands, with geographical distribution in the Brazilian Cerrado (Feitosa et al., 2011). Flowering occurs during the months of August and September. Astronium fraxinifolium is of great importance for the economy due to the high quality of timber production (Luna,

\section{"Corresponding Author}

Raphael de Oliveira Rodrigues, Department of Clinical Analysis and Toxicology, Faculty of Pharmacy, Universidade Federal do Ceara (UFC), 60430-370 Fortaleza, Brazil.E-mail: raphaelolrodrigues@gmail.com
2012). There is a great advantage in its use because it is not at risk of extinction. Medicinal purposes for the plant include the treatment of ulcers and infections (Macedo and Ferreira, 2004). Antimicrobial properties, such as antibacterial (Montanari et al., 2012), antifungal (Bonifácio et al., 2015), and leishmanicidal activities (De Lima et al., 2014), have been demonstrated.

According to phytochemical studies, the plant leaves present (Z)- $\beta$-ocimene, (E)- $\beta$-ocimene, bicyclogermacrene, limonene, $\alpha$-terpinolene, and viridiflorene (Montanari et al., 2012). Limonene bears anti-inflammatory and antioxidant activities (Złotek et al., 2016). Alpha-terpinolene is antifungal and leishmanicidal (Ramos et al., 2014). With respect to the antiinflammatory properties of $A$. fraxinifolium, scientific knowledge is still poor and needs to be better elucidated. 
Inflammation is a response of the immune system against invasive stimuli, infection, or tissue damage. It is a complex process regulated by various chemical mediators and immune cells (Guo et al., 2016). Macrophages are essential for achieving homeostasis, through the process of phagocytosis and production of chemokines, cytokines, and lipid mediators (Arulselvan et al., 2016). Lipopolysaccharide (LPS) is a component of Gram-negative bacteria outer cell membrane that induces macrophages to produce proinflammatory mediators, including iNOS, Cyclooxygenase- 2 (COX-2), tumor necrosis factor alpha (TNF- $\alpha$ ), and Nitric oxide (NO) (Lawrence et al., 2002), and Nicotinamide adenine dinucleotide phosphate (NADPH) oxidase (Singh et al., 2017). LPS-stimulated macrophages have been widely used to provide an in vitro inflammatory environment, which contributes, for instance, to study the role of anti-inflammatory compounds (Dong et al., 2017). Taking into account the limited scientific knowledge regarding the immunomodulatory properties of $A$. fraxinifolium, the present study aimed to evaluate its immunomodulating and antioxidant activities on LPS-stimulated RAW 264.7 cells.

\section{MATERIAL AND METHODS}

\section{Plant material}

Sapwood from A. fraxinifolium Schott (register at SISGEN A166486, 04/24/2018) was collected in the city of Lavras da Mangabeira (06 $45^{\prime} 12^{\prime \prime} \mathrm{S} 38^{\circ} 57^{\prime} 52^{\prime \prime} \mathrm{W} 239$ m), Ceara, Brazil. A voucher specimen (54265) was deposited at the Herbarium Prisco Bezerra, Department of Biology, Universidade Federal do Ceará, Brazil.

The plant material $(1,000 \mathrm{~g})$ was dried in an oven with forced air circulation for a period of 48 hours at $65^{\circ} \mathrm{C}$. Ethanolic extract was obtained by macerating the plant material with absolute ethanol for 7 days at room temperature. After the concentration of the material on a rotary evaporator under reduced pressure at $40^{\circ} \mathrm{C}$, the final extract (yield of $1.8 \%$ ) was submitted to phytochemical analysis.

\section{Phenol quantification}

Phenolic compounds in the ethanolic extract from the sapwood of $A$. fraxinifolium (EEAF) were quantified by the Folin-Ciocalteau technique (Singleton et al., 1965). The assay was performed in triplicate, using gallic acid (Sigma, USA) as the standard reference.

\section{Flavonoids quantification}

Flavonoid content in the EEAF was also quantified (Vennat et al., 1992). Quercetin (Sigma, USA) was used as the reference standard.

\section{Tannin quantification}

Tannin content was determined by the Folin-Denis colorimetric method (Galvão et al., 2018). Tannic acid (Sigma, USA) was used as the reference standard.

\section{High-performance liquid chromatography (HPLC)}

Chromatographic profile of the EEAF was done by the High-Performance Liquid Chromatography with Diode Array Detector (HPLC-DAD) on a Prominence high-performance liquid chromatography (HPLC) AutoSampler (SIL-20A) (Shimadzu, Kyoto, Japan), equipped with a Shimadzu LC-20AT pumps connected to a DGU degasser 20A5 with a CBM 20A integrator, SPD-M20A diode array detector, and LC solutions in software 1.2 SP1. EEAF and reference standards was injected into a Phenomenex C18-reverse-phase column $(4.6 \mathrm{~mm} \times 250 \mathrm{~mm})$. The elution was performed using mobile phases A (ultrapure water containing $2 \%$ acetic acid, $\mathrm{pH} 3.0$ ) and $\mathrm{B}$ (acetonitrile). Fifty microliters of the EEAF $(15 \mathrm{mg} / \mathrm{ml})$ were injected at a solvent flow rate of 0.6 $\mathrm{ml} / \mathrm{min}$. Reference standards were tested at $0.025-0.300 \mathrm{mg} / \mathrm{ml}$. Quantification of the compounds was performed by analyzing the peaks and their retention time $\left(t_{\mathrm{R}}\right)$, considering the optical reading for gallic acid (at $254 \mathrm{~nm}$ ), catechin (at $280 \mathrm{~nm}$ ), $\rho$-cumaric, acid and caffeic acid (at $325 \mathrm{~nm}$ ), quercetin (at $366 \mathrm{~nm}$ ), rutin, luteolin, and orientin (at $366 \mathrm{~nm}$ ). The chromatographic procedures were done in triplicate. The limit of detection and the limit of quantification were calculated according to Boligon et al. (2015).

\section{Evaluation of the antioxidant activity}

Inhibition of 2,2'-diphenyl-1-picrylhydrazyl (DPPH) activity

Analysis of the antioxidant activity of the EEAF extract was done by the 2,2'-diphenyl-1-picrylhydrazyl (DPPH) radical scavenging method (Brand-Williams et al., 1995), modified. The results were expressed according to the following formula: Inhibition percentage $(\%)=[\mathrm{Abs}(\mathrm{DPPH})-\mathrm{Abs}$ ( sample) $/ \mathrm{Abs}$ $(\mathrm{DPPH})] \times 100$, using quercetin as the reference standard. The assays were run in sextuplicate. Abs (DPPH) corresponded to the absorbance of the DPPH solution; Abs (sample) corresponded to the absorbance of the solution containing the EEAF extract at a determined concentration.

Inhibition of 2,2-azino-bis-3-ethylbenzothiazoline-6-sulfonic acid (ABTS) activity

Anti-oxidant activity of the EEAF extract was also tested by the 2,2-azino-bis-3-ethylbenzothiazoline-6-sulfonic acid (ABTS) method (Miller and Rice-Evans, 1997), modified. The percentage of inhibition was calculated according to the following formula: Inhibition percentage $(\%)=\left[\left(\mathrm{OD}_{\mathrm{ABTS}}-\mathrm{OD}_{\text {extract }}\right) /\right.$ $\left.\mathrm{OD}_{\mathrm{ABTS}}\right] \times 100$. The optical density $\mathrm{OD}_{\mathrm{ABTS}}$ corresponded to the optical density of the ABTS solution. The $\mathrm{OD}_{\text {extract }}$ corresponded to the optical density of the solution containing the EEAF extract at a particular concentration. The assays were carried out in triplicate.

\section{Evaluation of EEAF cytotoxicity}

The 3-[4,5-dimethyl-thiazol-2-yl]-2,5-diphenyltetrazolium bromide (MTT) tetrazolium assay (Rodrigues et al., 2019) was used to evaluate the viability of $R A W 264.7$ cells (BCRJ, Brazil) after treatment with the EEAF. RAW 264.7 cells $\left(5 \times 10^{5}\right.$ cells $\left./ \mathrm{ml}\right)$ were seeded into 96-well culture microplates in Dulbecco's Modified Eagle Medium (DMEM) (LGC, Brazil) supplemented with 10\% heat-inactivated fetal bovine serum (LGC, Brazil) and gentamicin (50 $\mu \mathrm{g} / \mathrm{ml}$, Sigma, USA), before incubation overnight at $37^{\circ} \mathrm{C}$ and $5 \% \mathrm{CO}_{2}$. After this period, the cells were treated with different concentrations of EEAF (15.63-500.00 $\mu \mathrm{g} / \mathrm{ml})$. After 24 hours incubation, the supernatant was discarded and the adherent cells were washed with phosphate-buffered saline (PBS). Subsequently, a new supplemented DMEM medium was pipetted into the wells, followed 
by the addition of(MTT, Sigma, USA) at $500 \mu \mathrm{g} / \mathrm{ml}$ in PBS. After a 4 hours-incubation at $37^{\circ} \mathrm{C}$ and $5 \% \mathrm{CO}_{2}$, the supernatant was discarded and $100 \mu \mathrm{l}$ of $100 \%$ dimethylsulfoxide (DMSO, Sigma, USA) were added to the plates. The plates were vigorously shaken for 15 minutes and the optical density was read at $570 \mathrm{~nm}$ wavelength using an Enzyme-linked immunosorbent assay (ELISA) plate reader. The assays were performed in triplicate.

\section{Plant activity on LPS-activated cells}

RAW 264.7 cells $\left(5 \times 10^{5}\right.$ cells $\left./ \mathrm{ml}\right)$ were incubated with LPS from Escherichia coli O128:B12 (Sigma, USA) at $1 \mu \mathrm{g} / \mathrm{ml}$ in a 24-well culture plate during 24 hours at $37^{\circ} \mathrm{C}$ and $5 \% \mathrm{CO}_{2}$. Nontoxic concentrations of EEAF $(31.25,62.5$, and $125 \mu \mathrm{g} / \mathrm{ml})$ and controls $(0.1 \%$ DMSO and $4.0 \mu \mathrm{g} / \mathrm{ml}$ dexamethasone, Sigma, USA) were added to the wells. After 24 hours, the cells or their supernatants were collected and analyzed.

\section{NO measurement}

NO measurement was indirectly assessed by the amount of nitrite in the cell culture supernatant using Griess reagent ( $1 \%$ sulfanilamide in $5 \% \mathrm{H}_{3} \mathrm{PO}_{4}$ and $0.1 \% \mathrm{~N}-(1$-naphthyl) ethylenediaminedihydrochloride), according to the procedure described by Rodrigues et al. (2019). Sodium nitrite (Sigma, USA) was used as the reference standard.

TNF- $\alpha$ and transforming growth factor beta (TGF- $\beta$ levels) measurement

Quantification of TNF- $\alpha$ and transforming growth factor beta (TGF- $\beta$ ) levels in cell supernatants was performed by using sandwich-enzyme immunoassays, according to the manufacturer's recommendations $\left(\right.$ Novex $^{\circledR}$, Life Technologies, USA).

\section{$m R N A$ for $C O X-2$, iNOS, and TGF- $\beta$}

Expression of mRNAs for COX-2, iNOS, and TGF- $\beta$ was evaluated by a reverse transcriptase-polymerase chain reaction technique. Extraction of RNA from LPS-stimulated RAW 264.7 cells after treatment with the $\operatorname{EEAF}(31.25,62.5$, and $125 \mu \mathrm{g}$ / $\mathrm{ml}$ ) was done using Trizol (Invitrogen, Carlsbad, CA), according to the manufacturer's instructions. Total RNA $(0.5 \mu \mathrm{g})$ was reversely transcribed into complementary DNA (cDNA) with the aid of the High-Capacity cDNA Reverse Transcription Kit (Applied Biosystems, USA), according to the manufacturer's recommendations. The sequences of nucleotides for designing targetspecific primers were obtained from NCBI and analyzed by the OligoPerfect ${ }^{\mathrm{TM}}$ Designer software (Thermo Fisher Scientific, USA). The following primers were used: COX-2, F: 5'-AGAAGGAAAT GGCTGCAGAA-3' and R: 5'-GCTCGGCTTCCAGTATTGAG3'; iNOS, F: 5'-CACCTTGGAGTTCACCCAGT-3' and 5'-ACC ACTCGTACTTGGGATGC-3'; TGF- $\beta, 5^{\prime}$-TTGCTTCAGCTCCA CAGAGA-3' and 5'-TGGTTGTAGAGGGCAAGGAC-3'; $\beta$-actin (housekeeping gene), F: 5'-AGCCATGTACGTAGCCATCC-3' and R: 5'-CTCTCAGCTGTGGTGGTGAA-3'. The number of amplification cycles was adjusted according to the target in order to obtain an exponential increase of the amplicons for each biomarker. The annealing temperature and the number of cycles used for the amplification of each target are described in Table 1. Reactions were performed using an 2720 Thermal Cycler (Applied Biosystems, USA). The amplicons were submitted to electrophoresis
Table 1. Target molecules and their optimized annealing temperature and the number of amplification cycles employed in the PCR amplification.

\begin{tabular}{lcc}
\hline Target & Annealing temperature $\left({ }^{\circ} \mathrm{C}\right)$ & Amplification cycles \\
\hline COX-2 & $60^{\circ} \mathrm{C}$ & 25 \\
iNOS & $55^{\circ} \mathrm{C}$ & 30 \\
TGF- $\beta$ & $60^{\circ} \mathrm{C}$ & 25 \\
$\beta$-actin & $60^{\circ} \mathrm{C}$ & 25 \\
\hline
\end{tabular}

on a $2.5 \%$ agarose gel followed by staining with SYBR Safe stain (Invitrogen, USA). The bands were visualized by a ChemiDoc ${ }^{\mathrm{TM}} \mathrm{MP}$ Imaging System (BIO-RAD, EUA) and their intensity was analyzed with the Image Lab ${ }^{\mathrm{TM}}$ software (version 5.1, BIO-RAD, USA).

\section{COX-2 detection by the western blot technique}

After treatment with the plant material or with the reference drug $(4.0 \mu \mathrm{g} / \mathrm{ml}$ dexamethasone, Sigma, USA), LPS-stimulated RAW 264.7 cells were lysed using Radio-Immunoprecipitation Assay (RIPA) buffer (Sigma, USA), which was supplemented with protease inhibitor cocktail P8340 (Sigma, USA) at 1:100 (v/v), phenylmethylsulfonyl fluoride (Sigma, USA) at $2 \mathrm{mM}$ and sodium orthovanadate (Sigma, USA) at $1 \mathrm{mM}$. Quantification of total proteins was done by the DC ${ }^{\mathrm{TM}}$ (detergent compatible) protein assay kit (Bio-Rad Laboratories, USA). Cell proteins ( $20 \mu \mathrm{g}$ per well) were electrophoresed on an 8\% sodium dodecyl sulfate-polyacrylamide gel, under a voltage of $125 \mathrm{~V}$ for 1 hour and 20 minutes at room temperature. The separated polypeptides were blotted onto a polyvinylidene fluoride membrane (Bio-Rad Laboratories, USA), under a constant amperage of $400 \mathrm{~mA}$, at $4^{\circ} \mathrm{C}$ for 2 hours. After blocking the membranes with Tris solution containing 5\% skim milk and 5\% bovine serum albumin (BSA) (Sigma, USA) overnight, they were incubated ( 2 hours) with primary rabbit antibody to COX2 (Santa Cruz Biotechnology ${ }^{\circledR}$, USA) at a dilution of 1:500 in 5\% BSA. Anti- $\beta$-actin antibody (Cell Signaling Technology, USA) was used as an internal reference standard. After the washing step (five times with Tris-buffered solution containing 1\% Tween 20), and incubated with the secondary peroxidase-conjugated anti-rabbit IgG (Cell Signaling Technology, USA), at 1:3000 dilution in 5\% BSA for 2 hours. For the chemiluminescence detection, luminol solution containing $\mathrm{H}_{2} \mathrm{O}_{2}$ (Amersham ECL ${ }^{\text {TM }}$ Prime reagent) was used. The membranes were photographed by a ChemiDoc ${ }^{\mathrm{TM}} \mathrm{MP}$ Imaging System (BIO-RAD, USA) and the Image $\mathrm{Lab}^{\mathrm{TM}}$ software (version 5.1, BIO-RAD, USA) was used for the image acquisition and edition.

\section{Statistical analysis}

Data were expressed as mean \pm standard error of the mean and analyzed by Student's $t$-test or analysis of variance, followed by Tukey's post-test. All analyses were performed using GraphPad Prism version 7.0 for Windows (GraphPad Software, San Diego, CA). The values considered statistically significant presented a value of $p \leq 0.05$.

\section{RESULTS AND DISCUSSION}

Spectrophotometric analysis of total phenols, flavonoids, and tannins was performed in the EEAF. Amounts equivalent to $60.00 \pm 1.538 \mathrm{mg}$ of total phenols, $1.159 \pm 0.851$ $\mathrm{mg}$ of flavonoids, and $48.94 \pm 0.037 \mathrm{mg}$ of tannins were found in 
$100 \mathrm{~g}$ of EEAF. According to Silva et al. (2010), Astronium sp. comprises flavonoids, proanthocyanidins such as profisetinidine and prorobinetinidine, tannins and lignins. The authors suggested that the condensed and hydrolyzable flavonoids and tannins found in the genus Astronium are responsible for certain characteristics such as astringency, and complexing with macromolecules, such as proteins, polysaccharides, and metal ions.

Phenols (e.g., gallic acid, caffeic acid, coumaric acid, rosmarinic acid) are produced as secondary metabolites and may present antioxidant and antimicrobial activities (Lin et al., 2016).

Figure 1 demonstrates the HPLC profile of the EEAF extract. Molecules from eight peaks were identified and quantified according to known concentrations of the standard solutions and their retention time $\left(t_{\mathrm{R}}\right)$, that is, caffeic acid $\left(t_{\mathrm{R}}=23.11\right.$ minutes, peak $3,5.12 \pm 0.01 \mathrm{mg} / \mathrm{ml})$ and quercetin $\left(t_{\mathrm{R}}=39.91\right.$ minutes, peak 7 , $2.19 \pm 0.01 \mathrm{mg} / \mathrm{ml})$, followed by orientin $\left(t_{\mathrm{R}}=32.15\right.$ minutes, peak $5,1.16 \pm 0.03 \mathrm{mg} / \mathrm{ml})$ and $\rho$-coumaric acid $\left(t_{\mathrm{R}}=29.86\right.$ minutes, peak $4,1.15 \pm 0.01 \mathrm{mg} / \mathrm{ml}$ ) (Table 2). The constituents of the extract were similar to those found by Martins et al. (2018) in the extract from the bark of $A$. fraxinifolium. Caffeic acid may present several biological properties, such as antioxidant and antimicrobial activities (Magnani et al., 2014), and anti-inflammatory activity by inhibiting the COX-2 enzyme (Erdemli et al., 2015). Quercetin is a flavonoid that bears antioxidant, anti-inflammatory, antibacterial,

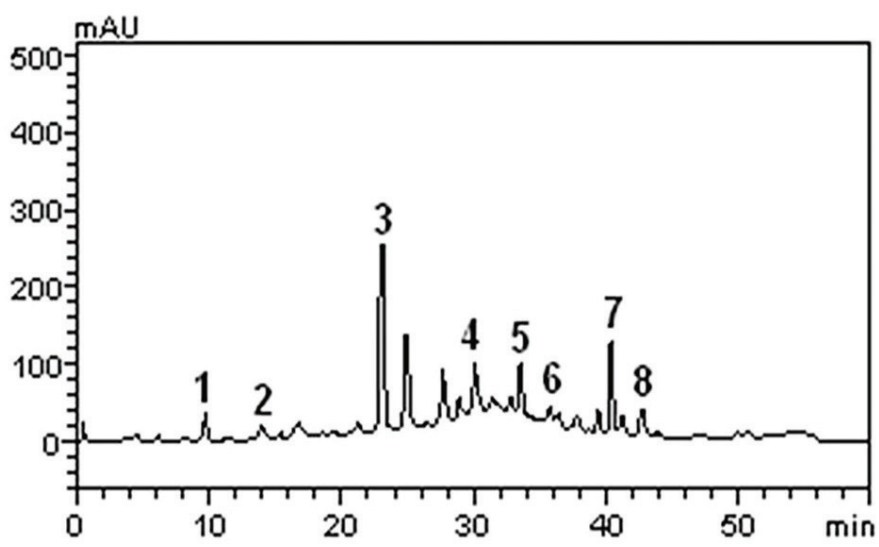

Figure 1. Chromatographic profile of the EEFA in HPLC-DAD. Peak 1: gallic acid, peak 2: catechin, peak 3: caffeic acid, peak 4: $\rho$-coumaric acid, peak 5: orientin, peak 6: rutin, peak 7: quercetin, and peak 8: luteolin.

Table 2. Compounds obtained from EEAF after separation by HPLC chromatography.

\begin{tabular}{clccc}
\hline \multirow{2}{*}{ Peaks } & Compounds & Ethanolic extract from the sapwood & LOD & LOQ \\
\cline { 3 - 5 } & & $\mathbf{m g} / \mathbf{m l}$ & $\boldsymbol{\mu g} / \mathbf{m l}$ & $\boldsymbol{\mu g} / \mathbf{m l}$ \\
\hline 1 & Gallic acid & $0.74 \pm 0.02$ & 0.009 & 0.034 \\
2 & Catechin & $0.39 \pm 0.03$ & 0.023 & 0.076 \\
3 & Caffeic acid & $5.12 \pm 0.01$ & 0.027 & 0.089 \\
4 & p-coumaric acid & $1.15 \pm 0.01$ & 0.015 & 0.047 \\
5 & Orientin & $1.16 \pm 0.03$ & 0.011 & 0.036 \\
6 & Rutin & $0.37 \pm 0.01$ & 0.018 & 0.061 \\
7 & Quercetin & $2.19 \pm 0.01$ & 0.013 & 0.047 \\
8 & Luteolin & $0.72 \pm 0.02$ & 0.007 & 0.023 \\
\hline
\end{tabular}

$\mathrm{LOD}=$ limit of detection, $\mathrm{LOQ}=$ limit of quantification. antiviral, gastroprotective, immunomodulatory, neuroprotection functions and is used in the treatment of obesity and cardiovascular diseases (Li et al., 2016). Luteolin, quercetin, and caffeic acid exert their immunomodulating properties by inhibiting nuclear factor kappa $\mathrm{B}$, with consequent decrease of interleukin (IL)-1 $\beta$ and TNF- $\alpha$ production (Juman et al., 2012).

First of all, we have tested the antioxidant activity of the EEAF. The $50 \%$ inhibitory capacity of free radicals of the EEAF was equivalent to $132.9 \pm 0.877 \mu \mathrm{g} / \mathrm{ml}$ for DPPH and $176.7 \pm 11.20 \mu \mathrm{g} / \mathrm{ml}$ for ABTS. The reference standard, that is, quercetin, was significantly more active than the $A$. fraxinifolium extract. The EEAF did not demonstrate a relevant antioxidant activity, differently from the results obtained by Martins et al. (2018). A large amount of EEAF would be necessary to neutralize the free radicals DPPH and ABTS in comparison to quercetin, the reference standard used in the experiments. Although quercetin was one of the constituents identified in the extract, it does not seem that it exerts a meaningful antioxidant activity in the EEAF, probably due to its low concentration in the extract.

Before testing the activity of the EEAF in the in vitro cell assays, cytotoxic analysis of the extract was done. The results revealed that concentrations equivalent to $500 \mu \mathrm{g} / \mathrm{ml}$ of EEAF on RAW 264.7 cells were toxic (Fig. 2). For this reason, concentrations lower than the mentioned ones were used in the following assays.

For NO measurement, it was observed that the mean concentrations of nitric oxide in supernatants from LPS-stimulated cells treated with EEAF at $31.25 \mu \mathrm{g} / \mathrm{ml}, 62.5 \mu \mathrm{g} / \mathrm{ml}$, and $125 \mu \mathrm{g} /$ $\mathrm{ml}$ were $11.83 \mu \mathrm{M}, 14.31 \mu \mathrm{M}$, and $13.15 \mu \mathrm{M}$, respectively. No statistically significant difference was found among the groups. The EEAF did not promote any nitrite production in unstimulated cells when treated with the highest concentration of the extract. Therefore, the EEAF did not interfere in NO levels (Fig. 3). In regard to mRNA for iNOS enzyme, a reduction of its expression

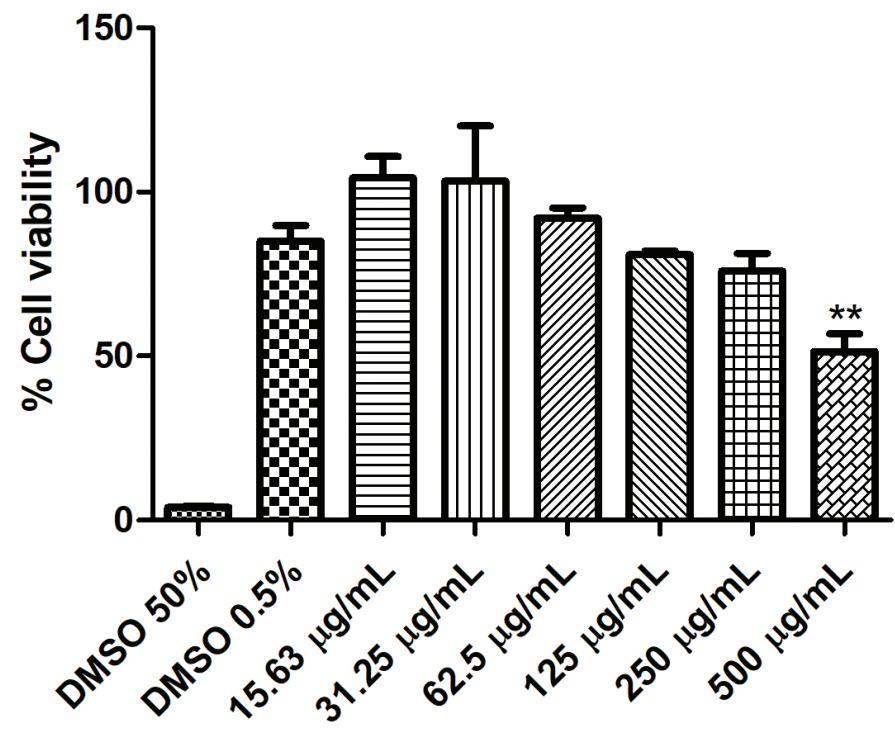

Figure 2. Cell viability assay using the MTT assay. RAW 264.7 cells were treated with EEAF at different concentrations $(15.63 \mu \mathrm{g} / \mathrm{ml} ; 31.25 \mu \mathrm{g} / \mathrm{ml} ; 62.5$ $\mu \mathrm{g} / \mathrm{ml} ; 125 \mu \mathrm{g} / \mathrm{ml} ; 250 \mu \mathrm{g} / \mathrm{ml} ; 500 \mu \mathrm{g} / \mathrm{ml})$. The control group was cultured in the presence of $0.5 \%$ of DMSO. ${ }^{* *} p<0.01$ versus Control (Student's $t$-test) 
was observed but without statistical significance (Fig. 4A). The pathways for the generation of oxygen and nitrogen species depend on the NADPH oxidase and iNOS inducible enzymes, respectively. Recently, it was demonstrated that NO presents paradoxal properties. NO has a powerful antimicrobial activity when it reacts with superoxide ion forming peroxynitrite; on the other hand, it is required for normal cardiovascular function. Therefore, it means that in order to achieve an adequate antioxidant activity, it is necessary that only NADPH oxidase activity be diminished (Sui et al., 2019).

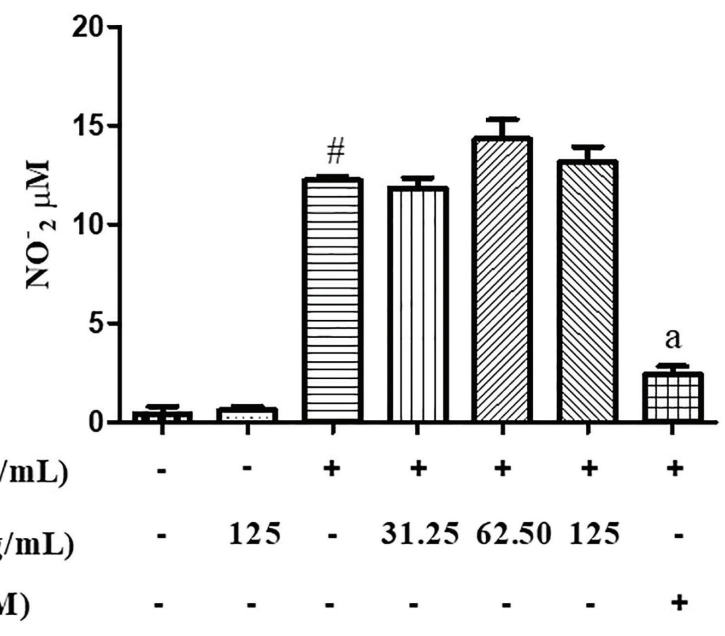

Figure 3. Nitrite $\left(\mathrm{NO}_{2}^{-}\right)$quantification in supernatants from LPS-stimulated RAW 264.7 cell submitted to different types of treatment. Controls: cell in $0.1 \%$ DMSO; LPS-stimulated cells; LPS-stimulated cells treated with $4 \mu \mathrm{M}$ dexamethasone; LPS-stimulated cells treated with EEAF at $31.25 \mu \mathrm{g} / \mathrm{ml} ; 62.5$ $\mu \mathrm{g} / \mathrm{ml} ; 125 \mu \mathrm{g} / \mathrm{ml}$. a $p<0.001$ versus LPS-stimulated cells; \# $p<0.001$ versus Control (Tukey's test).

$\mathbf{A}$

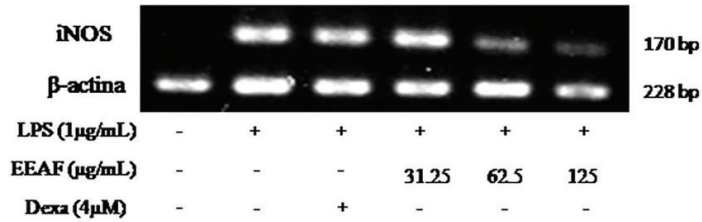

B

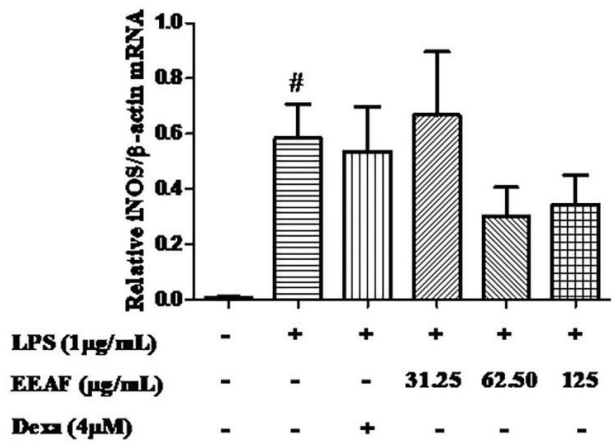

Figure 4. Expression of iNOS mRNA from LPS-stimulated RAW 264.7 cells treated with different concentrations of EEAF. Controls: Cells in 0.1\% DMSO; LPS-stimulated cells; LPS-stimulated cells treated with $4 \mu \mathrm{M}$ dexamethasone; LPS-stimulated cells treated with EEAF at $31.25 \mu \mathrm{g} / \mathrm{ml} ; 62.5 \mu \mathrm{g} / \mathrm{ml} ; 125 \mu \mathrm{g} / \mathrm{ml}$. $\# p<0.001$ versus Control (Tukey's test).
In respect to cytokine analysis, as demonstrated in Figure 5, all the concentrations of the EEAF induced a significant secretion of TNF- $\alpha$ in comparison to LPS-stimulated cells without treatment ( $p<0.001$; Tukey's test). The highest levels of the cytokine were found in the group treated with EEAF at $125 \mu \mathrm{g} /$ $\mathrm{ml}(p<0.001)$.

TNF- $\alpha$ is a cytokine that acts as an endogenous mediator, being able to stimulate IL- 6 and IL- $1 \beta$ secretion. The cytokines present synergistic effects among them, which amplifies the signaling pathway of inflammation (Ying et al., 2013). Interestingly, phenolic compounds may be classified from no action to strong activity in inhibiting TNF production (Grigore, 2017). It is important to remind that to inhibit TNF is an important target, mainly in inflammatory diseases such as arthritis (Henriques et al., 2016). Nonetheless, we have found increased levels of TNF- $\alpha$ in all groups treated with the EEAF in comparison to the untreated LPS-stimulated group. Allium sativum (garlic acid) has also the ability to stimulate the production of TNF- $\alpha$ by macrophages (Sung et al., 2015).

A significant decrease of TGF- $\beta$ was found when stimulated cells were treated with the EEAF at $31.25 \mu \mathrm{g} / \mathrm{ml}$ $(p<0.01)$, at $62.5 \mu \mathrm{g} / \mathrm{ml}$ and $125 \mu \mathrm{g} / \mathrm{ml}(p<0.001)$, in comparison to those untreated (Fig. 6). TGF- $\beta$ is an important immunomodulatory cytokine that has pleiotropic activity, acting on angiogenesis and in the repair phase of the inflammation (Poniatowski et al., 2015).

The treatment of LPS-stimulated RAW 264.7 cells with the EEAF at $62.5 \mu \mathrm{g} / \mathrm{ml}$ promoted an increase in COX-2 mRNA expression when compared to LPS-stimulated cells without treatment ( $p<0.05$, Fig. 7). Increased levels of COX-2 protein were also found in the LPS-stimulated cells treated with EEAF at $31.25 \mu \mathrm{g} / \mathrm{ml}$ when compared to LPS-stimulated group without treatment ( $p<0.05$, Fig. 8). COX-2 enzyme may be inducible by IL-1 and TNF and converts arachidonic acid to prostaglandins in macrophages and other cells leading to vasodilation, vascular

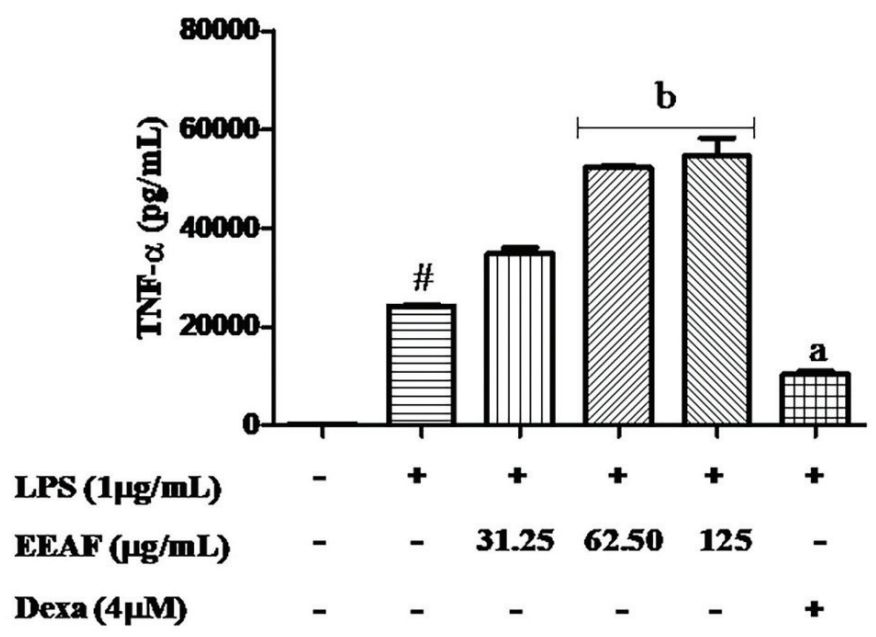

Figure 5. TNF- $\alpha$ measurement by ELISA in supernatants from LPS-stimulated RAW 264.7 cells treated with different concentrations of EEAF. Controls: cell in $0.1 \%$ DMSO; LPS-stimulated cells; LPS-stimulated cells treated with $4 \mu \mathrm{M}$ dexamethasone; LPS-stimulated cells treated with EEAF at $31.25 \mu \mathrm{g} / \mathrm{ml} ; 62.5$ $\mu \mathrm{g} / \mathrm{ml} ; 125 \mu \mathrm{g} / \mathrm{ml}$. a $p<0.001$ versus LPS-stimulated cells; b $p<0.001$ versus EEAF at $31.25 \mu \mathrm{g} / \mathrm{ml} ; \# p<0.001$ versus Control (Tukey's test). 


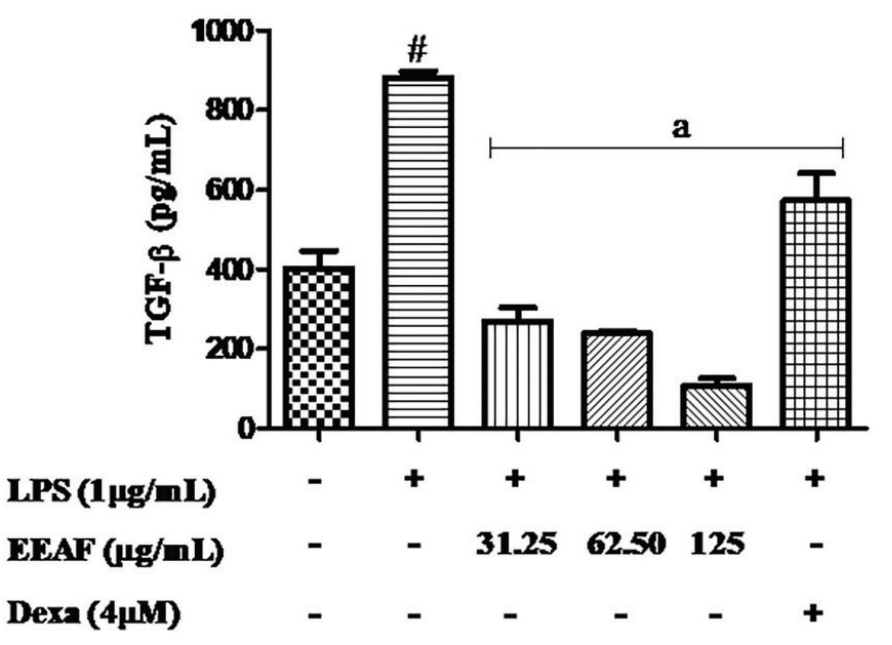

Figure 6. TGF- $\beta$ measurement by ELISA in supernatants from LPS-stimulated RAW 264.7 cells treated with different concentrations of EEAF. Controls: cell in $0.1 \%$ DMSO; LPS-stimulated cells; LPS-stimulated cells treated with $4 \mu \mathrm{M}$ dexamethasone; LPS-stimulated cells treated with EEAF at $31.25 \mu \mathrm{g} / \mathrm{ml} ; 62.5$ $\mu \mathrm{g} / \mathrm{ml} ; 125 \mu \mathrm{g} / \mathrm{ml}$. a $p<0.01$ versus LPS-stimulated cells; \# $p<0.001$ versus Control (Tukey's test).

$\mathbf{A}$

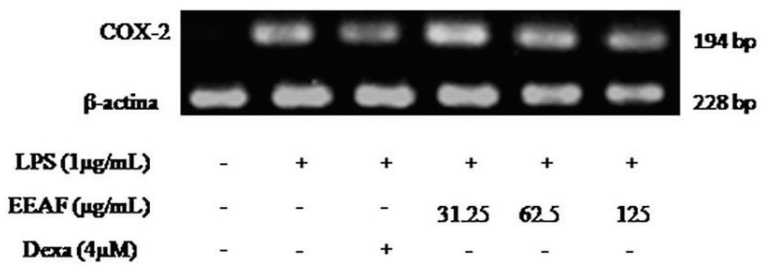

B

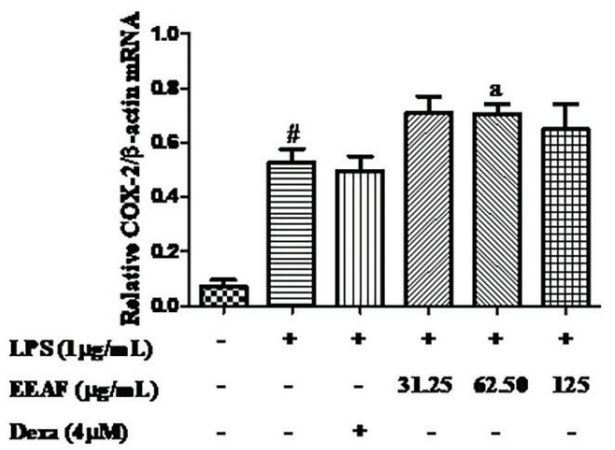

Figure 7. Expression of COX-2 mRNA from LPS-stimulated RAW 264.7 cells treated with different concentrations of EEAF. Controls: Cells in 0.1\% DMSO; LPS-stimulated cells; LPS-stimulated cells treated with $4 \mu \mathrm{M}$ dexamethasone; LPS-stimulated cells treated with EEAF at $31.25 \mu \mathrm{g} / \mathrm{ml} ; 62.5 \mu \mathrm{g} / \mathrm{ml} ; 125 \mu \mathrm{g} / \mathrm{ml}$. a $p<0.05$ versus LPS-stimulated cells; $\# p<0.001$ versus Control (Student's $t$-test).

permeability, fever, hyperalgesia, but paradoxically may produce lipid mediators with anti-inflammatory activity (Chen, 2010).

To increase the inflammatory response may be of great importance when the organism is chronically infected (Wang et al., 2016). Our present work was able to demonstrate that the EEAF makes macrophage more efficient in the production of inflammatory mediators which was evidenced by the increase in TNF- $\alpha$, COX-2, and a decrease in TGF- $\beta$. These results could
$\mathbf{A}$

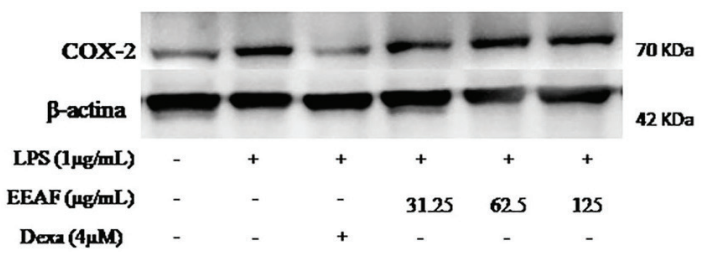

B

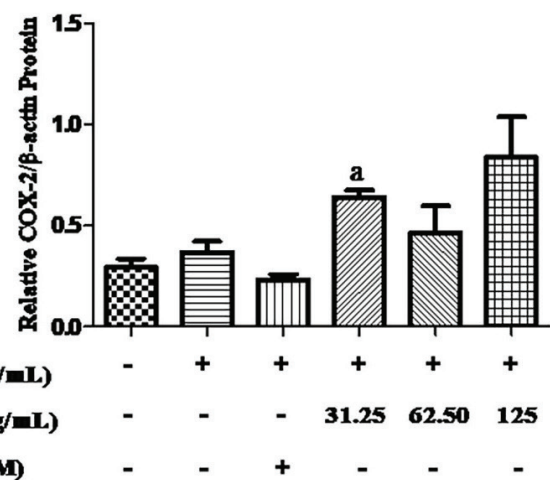

Figure 8. COX-2 measurement by Western blot technique in LPS-stimulated RAW 264.7 cells treated with different concentrations of EEAF. Controls: Cells in $0.1 \%$ DMSO; LPS-stimulated cells; LPS-stimulated cells treated with $4 \mu \mathrm{M}$ dexamethasone; LPS-stimulated cells treated with EEAF at $31.25 \mu \mathrm{g} / \mathrm{ml} ; 62.5$ $\mu \mathrm{g} / \mathrm{ml} ; 125 \mu \mathrm{g} / \mathrm{ml}$. a $p<0.05$ vs LPS-stimulated cells; $\# p<0.001$ versus Control (Student's $t$-test).

probably explain the reason for the potent leishmanicidal activity presented by $A$. fraxinifolium, demonstrated by in vitro and in vivo assays (De Lima et al., 2014). This is the first report which clearly demonstrates the proinflammatory activity of $A$. fraxinifolium sapwood.

\section{CONCLUSION}

In conclusion, in opposition to many different types of medicinal plants that show anti-inflammatory properties, the ethanolic extract from the sapwood of $A$. fraxinifolium presents a powerful pro-inflammatory capacity. This property may be extremely relevant in regard to the treatment of chronic infectious diseases based on medicinal plants. For this reason, studies are being conducted in order to evaluate the proinflammatory properties of EEAF in cells infected with Leishmania.

\section{ACKNOWLEDGMENT}

We would like to thank the Fundação Cearense de Apoio ao Desenvolvimento Científico e Tecnológico (FUNCAP, Ceará State Research Foundation), Coordenação de Aperfeiçoamento de Pessoal de Nível Superior (CAPES Foundation, Brazilian Ministry of Education), and Conselho Nacional de Desenvolvimento Científico e Tecnológico (CNPq, National Council of Scientific and Technological Development of Brazil) for provision of doctorate scholarship.

\section{CONFLICT OF INTEREST}

The authors declare that they have no conflicts of interest.

\section{FINANCIAL SUPPORT}

\section{None.}




\section{REFERENCES}

Arulselvan P, Tan WS, Gothai S, Muniandy K, Fakurazi S, Esa NM, Alarfaj AA, Kumar SS. Anti-inflammatory potential of ethyl acetate fraction of moringa oleifera in downregulating the NF-kappaB signaling pathway in lipopolysaccharide-stimulated macrophages. Molecules, 2016; 21:1452-65.

Boligon AA, Piana M, Kubiça TF, Mario DN, Dalmolin TV, Bonez PC, Weiblen R, Lovato L, Alves SH, Campos MMA, Athayde ML. A HPLC analysis and antimicrobial, antimycobacterial and antiviral activities of Tabernaemontana catharinensis A. DC. J Appl Biomed, 2015; 15:1-12.

Bonifácio BV, Ramos MA, Silva PB, Negri KMS, Lopes EO, Souza LP, Vilegas W, Pavan FR, Chorilli M, Bauab TM. Nanostructured lipid system as a strategy to improve the anti-Candida albicans activity of Astronium sp. Int J Nanomed, 2015; 10:5081-92.

Brand-Wiliams W, Cuvelier ME, Berset C. Use of a free radical method to evaluate antioxidant activity. LWT Food Sci Technol, 1995; 28:25-30.

Chen C. COX-2's new role in inflammation. Nat Chem Biol, 2010; 6:401-2

De Lima SC, Teixeira MJ, Lopes JE Jr, de Morais SM, Torres AF, Braga MA, Rodrigues RO, Santiago GM, Martins AC, Nagao-Dias AT. In Vitro and In Vivo Leishmanicidal Activity of Astronium fraxinifolium (Schott) and Plectranthus amboinicus (Lour.) Spreng against Leishmania (Viannia) braziliensis. Biomed Res Int, 2014; 2014:848293.

Dong L, Zhang Y, Wang X, Dong YX, Zheng L, Li YJ, Ni JM. In vivo and in vitro anti-inflammatory effects of ethanol fraction from Periploca forrestii Schltr. Chin J Integr Med, 2017; 23:528-34.

Erdemli HK, Akyol S, Armutcu F, Akyol O. Antiviral properties of caffeic acid 397 phenethyl ester and its potential application. J Intercult Ethnopharmacol, 2015; 4:344-7.

Feitosa D, Maltoni KL, Cassiolato AMR, Paiano MO Crescimento de mudas de Gonçalo-Alves (Astronium fraxinifolium) sob diferentes fontes e doses de nitrogênio. Rev Árvore, 2011; 35:401-11.

Galvão MAM, de Arruda AO, Bezerra ICF, Ferreira MRA, Soares LAL. Evaluation of the Folin-Ciocalteu Method and Quantification of Total Tannins in Stem Barks and Pods from Libidibia ferrea (Mart. ex Tul) L. P. Queiroz. Braz Arch Biol Technol, 2018; 61:e18170586.

Grigore A. Plant phenolic compounds as immunomodulatory agents. In: Soto-Hernandez M, Palma-Tenango M, Garcia-Mateos MdR (eds.). Phenolic Compounds-Biological Activity. : IntechOpen, Zagreb, Croatia, pp 75-98, 2017.

Guo C, Yang L, Luo J, Zhang C, Xia Y, Ma T, Kong L. Sophoraflavanone G from Sophora alopecuroides, inhibits lipopolysaccharide-induced inflammation in RAW264.7 cells by targeting PI3K/Akt, JAK/STAT and Nrf2/HO-1 pathways. Int Immunopharmacol, $2016 ; 38: 349-56$.

Henriques BO, Corrêa O, Azevedo EP, Pádua RM, de Oliveira VL, Oliveira TH, Boff D, Dias AC, de Souza DG, Amaral FA, Teixeira MM, Castilho RO, Braga FC. In Vitro TNF- $\alpha$ inhibitory activity of Brazilian plants and anti-inflammatory effect of Stryphnodendron adstringens in an acute arthritis model. Evid Based Complement Alternat Med, 2016; $2016: 9872598$.

Juman S, Yasui N, Ikeda K, Ueda A, Sakanaka M, Negishi H, Miki T. Caffeic acid phenethyl ester suppresses the production of pro-inflammatory cytokines in hypertrophic adipocytes through lipopolysaccharide-stimulated macrophages. Biol Pharm Bull, 2012; $35: 1941-6$

Lawrence T, Willoughby DA, Gilroy DW. Anti-inflammatory lipid mediators and insights into the resolution of inflammation, Nat Rev Immunol, 2002; 2:787-95.

Li Y, Yao J, Han C, Yang J, Chaudhry MT, Wang S, Liu H, Yin Y. Quercetin, Inflammation and Immunity. Nutrients, 2016; 8:167.

Lin D, Xiao M, Zhao J, Li Z, Xing B, Li X, Kong M, Li L, Zhang Q, Liu Y, Chen H, Qin W, Wu H, Chen S. An overview of plant phenolic compounds and their importance in human nutrition and management of type 2 diabetes. Molecules, 2016; 21:E1374.

Luna CV. Distribution and importance of the family Anacardiaceae timber in the gran chaco of Argentina. Ra Ximhai, 2012; 3:83-95.

Macedo M, Ferreira AR. Plantas medicinais usadas para tratamentos dermatológicos, em comunidades da Bacia do Alto Paraguai,
Mato Grosso. Rev bras farmacogn, 2004; 14: 40-4

Magnani C, Isaac VLB, Correa MA, Salgado HRN. Caffeic acid: a review of its potential use in medications and cosmetics. Anal Methods, 2014; 6:3203-10.

Martins AOBPB, Siebra ALA, Oliveira CDM, Leite GO, Coutinho HDM, Athayde ML, Bolignon AA, Andrade JC, Oliveira LR, Kerntopf MR, Barbosa R, Cesario FRAS, Coutinho TS, Quintans-Junior LJ,de Menezes IRA. Antimicrobial, gastroprotective and healing effect of the hydroalcoholic extract of Astronium fraxinifolium. Lett Drug Des Discov, 2018; 15:325.

Miller NJ, Rice-Evans CA. Factors influencing the antioxidant activity determined by the ABTSd+ radical cation assay. Free Radic Res, 1997; 26:195-9.

Montanari RM, Barbosa LC, Demuner AJ, Silva CJ, Andrade NJ, Ismail FM, Barbosa MC. Exposure to anacardiaceae volatile oils and their constituents induces lipid peroxidation within food-borne bacteria cells. Molecules, 2012; 17:9728-40.

Poniatowski ŁA, Wojdasiewicz P, Gasik R, Szukiewicz D. Transforming growth factor Beta family: insight into the role of growth factors in regulation of fracture healing biology and potential clinical applications. Mediators Inflamm, 2015; 2015:137823.

Ramos EH, Moraes MM, Nerys LL, Nascimento SC, Militão GC, de Figueiredo RC, da Câmara CA, Silva TG. Chemical composition, leishmanicidal and cytotoxic activities of the essential oils from Mangifera indica L. var. Rosa and Espada. Biomed Res Int, 2014; 2014:734946.

Rodrigues RO, Yaochite JNU, Braga MA, Sousa AR, Sasahara GL, Fonseca SGC, Araújo TDV, Santiago GMP, Sousa LM, Carvalho JL, do Nascimento FBSA, Nobre-Júnior HV, Nagao-Dias AT. Antioxidant and anti-inflammatory activities of Bauhinia ungulata L. (Fabaceae) on LPSstimulated RAW 264.7 cells. Pharmacogn J, 2019; 11:37-42.

Silva RMG, Saraiva TS, Silva RB, Gonçalves LA, Silva LP. Allelopathy potential of etanolic extract of Anadenanthera macrocarpa and Astronium graveolens. Biosci J, 2010; 26:632-7.

Singh A, Koduru B, Carlisle C, Akhter H, Liu RM, Schroder K, Brandes RP, Ojcius DM. NADPH oxidase 4 modulates hepatic responses to lipopolysaccharide mediated by Toll-like receptor-4. Sci Rep, 2017; 7:14346.

Singleton VL, Joseph A, Rossi J. Colorimetry of total phenolics with phosphomolibdic-phosphotungstic acid reagents. Am J Enol Vitic, $1965 ; 16: 144-9$.

Sui Y, Tian R, Lu N. NADPH oxidase is a primary target for antioxidant effects by inorganic nitrite in lipopolysaccharide-induced oxidative stress in mice and in macrophage cells. Nitric Oxide, 2019; 89:46-53.

Sung J, Harfouche Y, De La Cruz M, Zamora MP, Liu Y, Rego JA, Buckley NE. Garlic (Allium sativum) stimulates lipopolysaccharideinduced tumor necrosis factor-alpha production from J774A.1 murine macrophages. Phytother Res, 2015; 9:288-94.

Vennat B, Gross D, Pourrat H. Hamamelis virginiana: identification and assay of proanthocyanidins, phenolic acids and flavonoids in leaf extracts. Pharm Acta Helvetiae, 1992; 67:11-4.

Ying X, Yu K, Chen X, Chen H, Hong J, Cheng S, Peng L. Piperine inhibits LPS induced expression of inflammatory mediators in RAW264.7 cells. Cell Immunol, 2013; 285:49-54.

Złotek U, Michalak-Majewska M, Szymanowska U. Effect of jasmonic acid elicitation on the yield, chemical composition, and antioxidant and anti-inflammatory properties of essential oil of lettuce leaf basil (Ocimum basilicum L.). Food Chem, 2016; 15:1-7.

How to cite this article:

Braga MA, Rodrigues RO, Yaochite JNU, Sasahara GL, Viana AFSC, Nunes PIG, Melo KM, Santos FA, Teixeira MJ, Junior JTC, Rodrigues ALM, Morais SM, Dias ATN. Pro-inflammatory effect of Astronium fraxinifolium Schott on Lipopolysaccharide-stimulated macrophages. J Appl Pharm Sci, 2019; 9(12):030-036. 